\begin{tabular}{l|l|l|l|l}
\hline Volume 1 & Issue 2 & August (2020) & DOI: 10.47540/jsei.vli2.59 & Page: $91-96$ \\
\hline \multicolumn{4}{l}{} \\
Implementation of Leadership Strategies and Work Commitments in \\
Maintaining Employee Performance in CV. Silvana Print \& Advertising \\
Kendari City Southeast Sulawesi
\end{tabular}

\title{
Muhamad Masri
}

Department of Management, Halu Oleo University, Kendari City, Indonesia

Corresponding Author: Muhamad Masri; Email: masribones@gmail.com

\section{A R T I C L E I N F O \\ Keywords: Employee Performance; Leadership Strategy; Work Commitment.}

Received : 25 June 2020

Revised : 17 July 2020

Accepted : 08 August 2020

\begin{abstract}
A B S T R A C T
The purpose of this study was to determine the description of the application of leadership strategies and work commitments of CV. Silvana Print \& Advertising in maintaining employee performance. Data collection methods used were observation, open interview, and documentation. Analysis of the data in this research is a qualitative descriptive analysis through case studies. Based on the results of the study note that the leadership strategy and work commitment in maintaining employee performance on the CV. Silvana Print \& Advertising is done by controlling employees every day either directly or indirectly. Control is carried out related to the production process, optimizing the use of raw materials. Besides, leaders always provide ideas, instructions, and provide solutions to employees who have problems or obstacles, and leaders also use the WhatsApp group as a medium to help communicate with employees. Work commitment, the company applies work standards that can improve the quality of employees and pay attention to employee needs ranging from the needs of life, the needs of employees in production activities. Employee performance, in maintaining the company's employee performance, pay attention to the portion of work and ability of employees, ranging from the ability to initiate employees themselves, employee adaptation, creativity, discipline, experience, and employee cooperation.
\end{abstract}

\section{INTRODUCTION}

Printing is one of the primary media formats that is difficult to find a replacement for more than 500 years. Printing is even considered as one of the primary human needs (Watkins, 2012). Over time, printing has become an industry that has an increasing global demand trend. From year to year, more and more commercial printing manufacturers are found in various parts of the world including Indonesia.

In organizations, subordinates work always depends on the leader. If the leader cannot lead, then very complex tasks cannot be done well. If managers can carry out their functions properly, the organization can likely achieve its goals. An organization needs effective leaders, who can influence the behavior of their members or subordinates. So, a leader or head of an organization will be recognized as a leader if he can exert influence and be able to direct his subordinates towards the goals of the organization.

The quality of the leader is often considered as the most important factor in the success or failure of an organization as well as the success or failure of an organization, both business-oriented and public, usually perceived as the success or failure of a leader. The field of organizational behavior. Leaders play a key role in formulating and implementing organizational strategies.

This brings the consequence that every leader is obliged to pay serious attention to fostering, mobilizing, and directing all the potential employees in his environment to realize the volume and workload that is directed to the goal. Organizational commitment so that it can ultimately increase high performance.

In addition to leadership style, factors that can improve employee performance are employee work 
commitments at the organization or company. According to Sunarto (2005), commitment is love and loyalty consisting of statements with the goals and values of the company, the desire to remain in the organization, the willingness to work hard on behalf of the organization. Employees must also be committed to working in an organization or company. Employees who are committed to high work will have a sense of responsibility at work and maximum morale to do their work. While employees who are committed to low work tend to be lazy in doing work and are not enthusiastic about working. High commitment will make employees strong in facing challenges and pressures.

A person's commitment to the organization or company is very important, especially on one's performance when working. Every company wants its employees to have a high commitment. High commitment can encourage employees to work well. Organizational commitment shows one's confidence and support and loyalty to the values and goals that want to be achieved by the organization. Strong organizational commitment will cause individuals to try to achieve organizational goals, think positively, and try to do the best for the organization. This happens because individuals in organizations will feel they have an organization. While low organizational commitment will cause the individual to only concern himself or his group so. In the end, the individual's performance will be low in his organization. The low performance of individuals in their organizations due to the influence of low commitment will indirectly result in difficulty to achieve success on employee performance.

Especially in Kendari City, it can be seen from the many printing presses that have appeared. There are already 18 large printing presses that have been registered at A2PS (Association of Advertising \& Print in Southeast Sulawesi) and one of them is CV. Silvana Print \& Advertising. The company has two offices namely the head office which is located on Ir H Alala street, Bypass Kendari, and branch office located on Sao-Sao street, City of Kendari and Silvana itself have a workshop located on Wijaya Kusuma street, Kemaraya.

This company has also become a vendor publishing company PT. Philip Moris Indonesia (PT. HM Sampoerna Tbk). In carrying out its activities CV. Silvana Print \& Advertising has 16 employees namely 8 people who work as outdoor employees, and 8 people as indoor employees. With 15 Silvana employees able to handle work throughout Southeast Sulawesi, with the help of transportation in fulfilling their duties. Besides, Silvana also has several billboard points scattered in several regencies/cities in Southeast Sulawesi.

Of the many companies in the field of Print \& Advertising that compete in Kendari, it is clear that CV. Silvana Print \& Advertising is one of the largest companies, it is very important to have a good strategy to face competition from other companies to get customers and serve customers so that the level of customer satisfaction is achieved in this company. Besides, this company must also have a work strategy and commitment to maintain the performance of its employees. Where employees in this company have a high commitment and performance, and employees complete their solid work even though they have obstacles and pressures from various things.

Based on preliminary studies at the research location, work commitment to the company can be seen in terms of employee discipline that works outside the city or late at night but with a sense of loyalty and high responsibility for their work. Furthermore, in terms of performance, the employees can meet customer needs with limited work time but are still able to complete within the specified time. Leaders in this company also always provide input to employees related to their work so that each job can be completed with maximum results. And at the time of production error, the leader will go down directly in solving the problem. From the phenomena above, this research was conducted to find out the leadership strategies implemented by leaders in creating and maintaining work commitments and employee performance in CV. Silvana Print \& Advertising.

\section{Materials AND Methods}

This research method is qualitative. Qualitative method according to Bogdan and Taylor (Moleong, 2006), that qualitative methodology is a research procedure that produces descriptive data in the form of written or oral words from people and observed behaviors and attitudes to contribute in-depth knowledge about research objects. Descriptive nature aims to describe or describe a situation or object of research based on existing facts. 
This method was chosen because it is more able to determine the situation definition and social phenomena of the subject, behavior, subjective motives, feelings, and emotions of the people observed is the situation definition of the subject under study. Then the subject will be examined directly. Other than that this method can improve the researcher's understanding of the subject view and interpret his life because it relates to the subject and his world, not in an unnatural world created by researchers.

Analysis of the data used in this study is a descriptive analysis that aims to interpret the informants' arguments about the questions and the frequency distribution of informant statements from the data that has been collected. In the process of data analysis, researchers refer to the definition of Sugiyono (2012), where data analysis consists of the process of educating data, presenting data, and making conclusions. In testing the validity of the data the researcher uses source triangulation techniques, where the intended triangulation of sources is to test the credibility of the data carried out by checking the data obtained through several sources. Then described, categorized which views or arguments are the same, which are different and which are specific from the various data sources are then used as a conclusion.

\section{RESULTS AND DISCUSSION}

After the data is known based on the facts of the meeting, then as a follow-up of this research is to analyze the data collected using a descriptive qualitative method in detail. Application of leadership strategies in CV. Silvana Print \& Advertising by:

1. Leadership as an innovator in this company, leaders as innovators monitor directly and provide instructions, provide ideas, and provide appropriate technical direction that will be used by employees regarding work to employees.

2. Leadership as a communicator. The application was made by the company leader's CV. Silvana Prit \& Advertising Kendari, Southeast Sulawesi as a communicator that is by communicating with employees every day to strengthen relations with employees, as well as the leadership also makes the WhatsApp group so that they can interact related to work problems both at work hours and outside working hours, and verbal appreciation of the work results of employees, besides the leader, is also a liaison employee talks to consumers when employees do not understand the words or intentions of orders from consumers so that the leader directs to employees the purpose of consumer demand, be it consumer design concepts, placement of points installation of customer orders, as well as liaison between employees and other employees such as the delivery of a designer, is not understood by the operator, the leader aligns the designer's intentions related to consumer orders

3. Leadership as a motivator. The leader is a motivator in this company, by monitoring employees both directly or indirectly by using CCTV when there are problems faced by employees, or more employees are at the point of being bored, then the leader will motivate employees by encouraging employees, and looking for solutions to the employee's problems.

4. Leadership as a controller. In this company, the leader as a controller controls his employees every day directly or with the help of managers and leaders monitor employee activities through CCTV, with the aim that these employees work by optimizing the materials used so that not much material is wasted or damaged, and the leader also control employees to maintain the machine properly and correctly. Implementation of the leader strategy $\mathrm{CV}$. Silvana Print \& Advertising in creating work commitments for employees by:

1. Embed in employees so that employees have a strong desire to remain as an employee in this company. For this strategy to be fulfilled, the leader can overcome the living needs of employees as much as possible, starting from setting salary standards, THR standards following government regulations (1-time salary for employees who have ten years of service), giving food allowances, monthly attendance bonuses, overtime bonuses, design bonuses and BPJS health insurance. On the other hand, the leader provides a comfortable workplace for employees, ranging from complete facilities, giving an appreciation of the results of the working end of the employee, and the leader provides opportunities for 
employees to ease the burden of their lives such as providing subsidies for employees' homes, mobile phones, and two-wheeled vehicles.

2. Embed in employees so that employees have the desire to try hard for the success of the company. leaders encourage employees, leaders inspire employees, work according to company operational standards, be it on discipline, neatness, friendliness, smiles, greetings, and greetings to customers, have integrity, have responsibility for their work, and work professionally so that they appear through the willingness to work beyond what is expected so that the organization can progress. Highly committed employees also pay attention to the fate of the organization.

3. Equality in organizational values. The leadership directs employees to have a personal work discipline, as well as coordinating employees to comply with all regulations that have been applied in this company, both regarding the tidiness of time discipline and accuracy.

4. Equality in organizational goals. This company has a goal which is to produce high-quality and high-value products. To produce products that fit the goals of the organization, leaders provide adequate facilities, good raw materials, and make employees comfortable at work. With the aim of this company, employees will realize that to produce products that are in line with the company's goals, there will be a sense of self within the employee to improve the quality, skills, and accuracy of employees, and improve employee performance.

Implementation of the leader strategy CV.

Silvana Print \& Advertising in maintaining employee performance by:

1. The quantity of work. In terms of work quantity, the leader applies the concept of "The Right Man in the Right Place" and considers work time, the amount of energy used, and the responsibility for the job so that each employee is equal to the ability of employees, so that there will be an increase in employee productivity.

2. Quality of work. Related to the quality of work the leader provides adequate facilities to support every job, and also the leader provides innovation to employees to increase employee knowledge and creativity so that employee work can be optimized, on the other hand, the leader also provides rewards and appreciation for the work of employees with the goal is that employees are motivated to improve their quality.

3. Independence. Head of CV. Silvana Print \& Advertising provides hints about things that employees don't know about work, and leaders provide opportunities for employees to develop by improving employee experience, this is done by leaders so that employees can carry out tasks independently, and minimize assistance from another employee.

4. Initiative. Leaders see employees in doing their jobs and provide motivations to arouse employee initiative, the flexibility of thinking of employees so that employees can develop their abilities and can also be willing to accept responsibilities related to work provided independently.

5. Adaptability. Leaders implement a system where for new employees the leader provides a 3-month training period to adapt to regulations, operational standards, the company's environment, as well as with other employees and the leader assesses and accepts from other employee assessments, whether the employee can adapt or not. The leadership also provides freedom and instructions for employees to adapt to the machines that are used related to problems in the use, maintenance, and solving machine problems that occur.

6. Cooperation. In the case of collaboration, the leader makes a work team where the leader combines by assessing employees who have a lot of experience and who have less experience, with the aim that they can work together, and employees who still lack experience can learn with employees who have a lot of experience. In making this work team the leader also ranks the members of this work team so that cooperation between employees is evenly distributed so that no inappropriate employees are doing their jobs. On the other hand the leader also always provides input to the employee when his work is finished and there is no more work for him, then the employee helps other employees in doing their work so that cooperation between employees is always 
running and employees are always compact and solid.

\section{CONCLUSION}

Based on the research results discussed in the previous chapter, the following conclusions can be drawn:

1. The leadership strategy was implemented by the leadership of CV. Silvana Print \& Advertising is leadership as an innovator, communicator, motivator, and controller. Where in its application the leadership of CV. Silvana Print \& Advertising Leaders monitor directly and provide instructions, provide ideas, and provide appropriate technical direction that employees will use related to work to employees, communicate with employees every day, and leaders also create WhatsApp groups for all employees, the leader is also the liaison employee talks to consumers. The leader encourages employees and helps find solutions to solutions to the employee's problems. The leader also controls employees in optimizing the materials used, as well as controlling in terms of maintaining the machine properly.

2. The leadership strategy was implemented by the leadership of CV. Silvana Print \& Advertising in creating work commitments namely Creating within employees to have a strong desire to remain as employees in the CV. Silvana Print \& Advertising, Hard Endeavor For Organizational Success, Equality of Organizational Values, and Equality of Organizational Goals. The strategy is implemented in a way that the leader can overcome his needs as far as possible, by setting salary standards, THR granting standards, meal allowances, month-long attendance bonuses, overtime bonuses, design bonuses, and backed up with BPJS health insurance, BPJS employment, providing a comfortable workplace and provide adequate facilities, prepare good materials and capable equipment, provide subsidies such as houses, mobile phones, and motor vehicles. The leader demands that employees work according to the company's operational standards, be it on discipline, neatness, friendliness, smiles, greetings, and greetings to customers, have integrity, have responsibility for their work, and work professionally.

3. The leadership strategy was implemented by the leadership of CV. Silvana Print \& Advertising in maintaining employee performance namely the quantity of work, the quality of work, independence, initiative, adaptability, and cooperation. In its application the leadership of CV. Silvana Print \& Advertising carries out the concept of "The Right Man in The Right Place" by paying attention to the portion of work, based on the ability of employees and responsibilities for the work equally for each employee. Giving innovation to employees, giving instructions to employees, providing motivation, generating initiative for each employee, the leader will also see the work of employees, the professionalism of employees, increase employee discipline, and provide additional rewards or bonuses for disciplined employees, and improve employee experience so that employees can carry out their tasks independently, and also the leader emphasizes to employees to always develop the ability of employees to communicate between employees and customers or employees with employees, the Leader also provides freedom for employees to adapt to the machines that are used related to problems of use, maintenance, and solving machine problems that occur, the leader makes the work team, and the leader also ranks the members of this work team so that cooperation between employees is evenly distributed so that there are no employees who are not suitable to do their jobs.

The leadership strategy and work commitment can maintain employee performance, because where the leadership strategy and work commitment implemented by this company as well as the steps taken by the leadership to achieve these strategies is quite good in improving employee performance.

\section{REFERENCES}

Anthony, Robert N. dan David W. Young. (2003). Management Control in Nonprofit Organizations, 7th Ed. McGraw - Hill.

Arifin, Anwar. (1998). Ilmu Komunikasi Sebuah Pengantar Ringkas. Jakarta: Raja Grafindo Persada. 
Bernardin and Russel. (2014). Human Resource Management. New Jersey: International Editions Upper Saddle River, Prentice-Hall.

Donni Junni Priansa. (2014). Perencanaan \& Pengembangan SDM. Bandung: Alfabeta.

Harbani, Pasolong. (2013). Kepemimpinan Birokrasi. Bandung: CV. Alfabeta.

Luthans Fred. (2006). Perilaku Organisasi. Yogyakarta: Andi.

Mathis, R.L., and Jackson J.H. (2008). Human Resource Management, 12th ed. Mason, Ohio: Thomson South-Western.

Moleong, J, Lexy. (2006). Metodologi Penelitian Kualitatif. Bandung: PT. Remaja Rosdakarya.

Robbins, Stephen P \& Judge, Timothy A. (2013). Organizational Behavior Edition 15. New Jersey: Pearson Education.

Sugiyono, dan Husein Umar. (2002). Metode Penelitian Bisnis. Bandung: Alfabeta.

Sugiyono. (2012). Metode Penelitian Kuantitatif Kualitatif dan $R \& D$. Bandung: Alfabeta.

Sunarto. (2005). Manajemen Sumber Daya Manusia Strategik. Yogyakarta: Amus.

Thoha, Miftah.

(2010). Kepemimpinan dalam Manajemen. Jakarta: PT. Raja Grafindo Persada.

Watkins, Diana. (2012). Factors Contributing to the Success of Commercial Printers. Thesis, Rochester Institute of Technology. 